\title{
Engaged Ethics in the Time of COVID: Caring for All or Excluding Some from the Lifeboat?
}

\author{
Paul James (D)
}

Received: 17 June 2020 / Accepted: 29 September 2020

(C) Journal of Bioethical Inquiry Pty Ltd. 2020

\begin{abstract}
If good ethics is the process of ongoing dialogical deliberation on basic normative questions for the purpose of instituting principles for action, then the COVID crisis, or any crisis, is not a good time for developing ethical precepts on the run. Given dominant ethical trends, such reactive ethics tends to lead to either individualized struggles over the right way to act or hasty sets of guidelines that leave out contextualizing questions concerning regimes of care. Good people will find themselves suggesting strange things, from setting up lifeboat scenarios to supporting structural racism. This essay argues against both these paths - crisis-ridden agonism or algorithmic resource-allocation - and turns instead to a form of ethics of care which takes its departure from older forms of ethics, while recognizing that modern and postmodern challenges no longer allow their grounding in animated relations, natural rights, or cosmological truths.
\end{abstract}

Keywords Ethics of care $\cdot$ Modern ethics $\cdot$ Postmodern ethics $\cdot$ Crisis

What does it mean to act ethically in the time of COVID-19? Alternatively, we might ask, what does it mean to develop an ethics in response to the COVID crisis? These are two very different questions, and given

P. James $(\square)$

Institute for Culture and Society, Western Sydney University,

Locked Bag 1797, Penrith, NSW 2751, Australia

e-mail: paul.james@westernsydney.edu.au the working premise of this essay - namely, that ethics can be defined as the process of ongoing dialogical deliberation on basic normative questions of human practice for the purpose of instituting principles for good action-these questions have very different consequences. It sounds like hair splitting, but the first question, based on what might be called an engaged ethics, I will argue, is critically important. The second, based on a reactive ethics, has the tendency to distort good practice.

The key point here is that, rather than being developed ex nihilo or as a narrow response to a particular crisis situation, an ethics should ideally be developed in relation to the human condition as understood both in and across time and place. In fact, I would suggest that a crisis is the worst time to develop an ethics. Crises are arguably times for thinking through and applying already-developed and well-debated ethical frameworks. They are not for thinking and acting on the spot.

The current tendency towards taking seriously the question posed in a reactive register seems to be leading either to individualized and crisis-ridden agonism (usually a struggle with oneself) or to ethical algorithmics and systems of codified decision-making (usually a set of precepts handed down to others). I say this carefully. These are tendencies. There is usually a comforting rhetoric associated with such tendencies which disavows the dominant direction of their approaches and which makes it crucial to read them with critical care.

The first tendency is illustrated by the difficult and important decisions that individuals are now making every day as they avoid people on the street or decide 
whether or not to visit a distressed loved one. Does one establish eye contact with a stranger when giving that person a wide berth in the street? Is the other person being antisocial by wearing a mask - or by not wearing a mask? Should you tell those wearers and non-wearers your views on the matter? Is it $\mathrm{OK}$ to visit an aged parent during a physical distancing period, or not? Do black lives matter more than possibly spreading the COVID infection? And, if I decided not to go to the "Black Lives Matter" rallies, is it now OK to go to the football? All of these are confronting and personal decisions. Ideally, one's responses to them should be based on personal reflection and social dialogue rather than just "what feels right." This kind of ethics is a relativizing ethics of agonism - not unimportant but only one way of making ethical decisions. ${ }^{1}$

The second tendency is illustrated by the number of discussions initiated during the COVID crisis about who should be supported medically when there are scarce resources. One lineage of modernist ethics reverts to algorithmic-like guides, where the ontological form of that kind of decision-making is left as an uninterrogated black box while the details of how one should act are supposedly made clear. Who should get a ventilator when there are not enough for everyone? Who should be supported by intensive care? Unfortunately, when life-and-death questions hit us, this constructivist lineage of thinking all too quickly moves to devise guiding codification systems that legitimize and indeed push certain outcomes. For example, they direct a medical practitioner to choose between this or that patient as "high priority" or "low priority." My critique will become damning here, but just as I do not want to dismiss relativizing ethics altogether, I will also seek to recuperate constructivist ethics (suggesting that both need to be reflexively re-engaged in a larger understanding of what it means to act ethically).

Reactive constructivist approaches typically go down the path of resource-allocation frameworks:

\footnotetext{
${ }^{1}$ Agonism, referring to the struggle with one's self in the process of deciding what is "good" or "right," is treated here as a form of postmodern ethics to the extent that there is afforded no ground upon which to stand except the particularism of where you happen to be or feel at the time. Rosi Braidotti's nomadic ethics (2006) exemplifies this kind of particularistic mobile ethics. Even as, like many postmodernists, she tries to reject the critique of relativism, she offers no standpoint other than that of the "nomadic, dispersed, fragmented" subject (2006, 4). For a more reflective and non-individualistic version of postmodern ethics, see Zygmunt Bauman's Postmodern Ethics (1993).
}

How Should We Prioritize Patients who are Eligible for Admission to ICU?

How exactly this is done may depend on local circumstances. To simplify, we will consider allocation to two main groups:

(a) High Priority: Those who, on the basis of their current medical condition, are highly likely to re- cover and would benefit long-term from admission to the ICU.

(b) Low-Priority: Those who, on the basis of their current medical condition, may recover after admission to the ICU.

This is, mainly, a medical judgement, and as such it will take into account multiple factors about each individual patient, including the medical condition of the patient, their expected tolerance of the treatment, the expected outcomes of treatment, the existence of co- morbidities where these are relevant to expected benefit, etc. Decisions should not be made simply on the basis of age, but other things being equal, length and quality of expected post-ICU life will be relevant. These overall judgements are to be driven, ultimately, by the key idea of "best value" use of any resource. (Dawson et al. 2020, Step 3 under "6. How Should We Decide How to Allocate Scarce Resources?" [University of Sydney Health Ethics])

Why, during a time of crisis, is a patient's recovery potential the key to understanding whom we should prioritize in giving care? In this case the answer to that question is clothed in a (tautological) claim that assumes the self-evidence of the issue. First, say the authors of this document, "once resources are scarce our primary obligation is to ensure that we gain the best value we possibly can from the expenditure of that resource" (Dawson et al. 2020, I1 under "6. How Should We Decide How to Allocate Scarce Resources?"). Second, the meaning of "best value" is assumed to coincide with best recovery rate. And why should this be the case? In this document the answer is contained in just one sentence: "we believe we are obliged to focus on using scarce resources as efficiently as possible, and at this crucial point we must focus on 'best value"” (Dawson 
et al. 2020, Step 3 under "6. How Should We Decide How to Allocate Scarce Resources?", emphasis added). Round and round the modernist efficiency circle the argument goes, with the phrase "we believe" offering the only way out of the tautology. In the words of Bryan Mukandi, written in response to a parallel move by different authors, "They view COVID-19 not as a something that has emerged over time as a result of our social configuration and political choices, but as something that appeared out of nowhere, an atemporal phenomenon" (2020, \[1).

Lest it be thought that this kind of healthrationalist thinking is unusual, let me quote recent comments by the vice chancellor of Melbourne University, Duncan Maskell, to the Australian national press. "The question everyone is skirting around here," he says, "is what is the appetite in any country for disease and mortality associated with this virus" (Le Grand 2020, II4). If a decision to lockdown social interaction now, with all its economic consequences, has consequences for future mortality, then it "would be crazy if, hypothetically, we stop 100 people [dying] from the virus but over the next two years, 200 people died from [the effects of] poverty and mental health" (Le Grand 2020, I66). This is a real question, but it works more like a debating point if it is not located in a larger context. One issue, among many, is that such a position is non-verifiable except perhaps in retrospect. A second is that such consequentialist ethics tends to be blinkered and narrow in its focus. Why has that question of priorities come to the fore when, on the one hand, across the world, mostly in subSaharan Africa, a child dies every five seconds from poverty-related causes, and on the other hand, our record of financial support is meagre and declining. Duncan Maskell's way out is to turn to an algorithmic health-calculation called QALY - quality-adjusted life years. We should be looking after those who have the longest to live with the best quality of life, he suggests: "It boils down to a basic but very hard moral philosophy: What is the value of a 90 year-old's life versus the value of the continuing livelihood and happiness of a 25-year-old?" (Le Grand 2020, II8).

These kinds of judgements-from-nowhere are the basis of one of the most influential contemporary constructivist approaches to ethics-John Rawls' A Theory of Justice (1971). Rawls suggests that agreement about a set of general principles can be achieved through positing a hypothetical group of rational persons from whom all the particularities and identities and attachments of their lives have been abstracted. He places this group behind a "veil of ignorance." From that position any knowledge that persons have of their own standing in the world is stripped away. They are, in effect, lifted into the position of being universal persons (aka modern liberals) with no conception of what this world looks like. They are afforded-or, in this case, reactive constructivists afford their systems of decision-making - the condition of supposed neutrality. This allows for different variations on codified processes and lists to take over from the complexity of particular situations, whether it be "best value" calculations or QALY assessments.

Locating these questions in actual examples shows how dangerous such codified decision-making could be. If, for example, recovery from COVID-19 is affected by the social conditions of health, and if an Aboriginal person and an African-American person are on a ward needing care alongside a middle-class non-Aboriginal person, given that two of those persons are more likely to come from a health-affected background (Millett et al. 2020; Fouad et al. 2020), then a decision based on the potential for patient recovery as to whether or not they are of a "high priority" or "low priority" would lead our reactive constructivists down the path of confirming the outcomes of structural racism. By the same argument, if a disabled person is judged as having a lower QALY assessment, and this leads to deprioritizing their healthcare, then we are confirming another kind of abstracted discrimination.

Unfortunately, these two alternative orientations to ethics - an agonistic form of relativizing ethics and a codifying form of constructivist ethics-have become central to mainstream ethics with little interrogation of their ontological grounding. And in the current period we tend to jump between the best and worst versions of them according to what we feel seems most appropriate. As individuals we tend towards agonism, and as members of institutions we tend towards semi-systematic codification. Codification is the chosen path of the Sydney University writers and the University of Melbourne vice chancellor, but with the words "we believe" or "my personal view is," those authors also allow themselves a flip back into an unstated relativizing ethics. 
Both directions, the first postmodern in orientation (relativizing the basis of ethics) and the second modern (constructing the terms for ethical judgement), potentially make valuable contributions to ethical dialogue, but each tends to operate as if offers a singular choice. My argument is that these choices are not good in themselves. If, on the one hand, it is argued that the COVID crisis entails remaking the basis for ethical considerations, then we have entered the world in which ethics has been relativized as postmodern agonismthat is, as particularized standpoints, with each having its own validity. In this world, there is no stable foundation to thinking about good action. From this standpoint, persons, communities, and organizations face such new and confounding complexities that ethical issues can only be confronted by thinking on the run.

If, on the other hand, it is argued that we should set up codification principles for what amounts to survival of the fittest, we risk returning to the deeply skewed "neutrality" of lifeboat ethics. Lifeboat ethics has an inglorious history, most famously used by Garret Hardin (1974) to argue that in these times where the earth's population makes the planet unsustainable there is no point in affording valuable resources to the poor (or elderly). Lifeboat ethics is built on an apparently simple story. Only a certain number of people can fit on the boat that will save lives. Who are you going to choose and on what basis? Will it be the fittest, those who will make the greatest contribution to future survival, or the most vulnerable, etc.? Hardin concludes that we, the rich, need to choose ourselves because otherwise the poor will overrun the planet through excessive procreation. Like game theory and rational choice politics, this kind of ethical standpoint abstracts from social life to give the impression that such situations actually exist in the world. However, even an intensive-care ward is located in a hospital, and a hospital is located in a region, usually with other hospitals, and a region is part of territory with other resources, capacities, and possibilities, all of which are relevant here. In other words, resource-allocation questions should involve layered political and ethical debates across constituents and citizens. Any logic that reduces human value to numeric indicators, as María Antonia González Valerio and Rosaura Martínez Ruiz write, is "to reduce the possibilities for thought, and abruptly to turn philosophy itself into a hideous ideology of discrimination, exclusion, and necropolitics" (2020, \[4).
The tension between constructivist and relativist ethics does provide an alternative, but it is one that is largely forgotten in the reactive register - an ethics of care. ${ }^{2}$ Its primary orientation is constructivist but without being narrowly codifying. It gives no straightforward answers, but in the version that I would like to project it has the capacity to build upon older forms of ethics - what I will call analogical ethics and cosmological ethics - while responding to the "end of certainty" arguments which dismiss the foundational claims of these older approaches.

Analogical ethics, once dominant in customary societies, emphasizes the right way to sustain embodied relations between persons and persons, and between persons and animals or things, by working analogically from animated nature-culture. An ethics of care can be developed that emphasizes the relational nature of ethical work without depending upon analogical and perceptual grounding or romanticizing animist understandings. Here lived relations of face-to-face reciprocity, mutuality, and even negotiated boundary-crossing become acutely relevant to contemporary ethics, translated for very different and more abstracted layers of social life.

Cosmological ethics, once dominant in traditional societies, emphasizes the Transcendental or Natural basis (in capital letters) of ethical decision-making-for example in the tradition of Christianity, removed from the lives of mere mortals and, at the same time, returned to the flesh as a sustaining lived metaphor of the exemplary-sacred. Cosmological ethics provides a more abstract way of approaching an ethics of foundations than analogical ethics. It tries to get to the bottom of the meaning of life by abstracting from analogical ethics in three ways: firstly, it finds exemplary carriers of meaning such as Jesus, Buddha, and Mohammed; secondly, it begins to codify rules for living that are written outside the stories of the law-givers - the Ten Commandments, the Halacha, Sharia, Dharma, and so on; and thirdly, it begins to reflect upon an ethics of care through axioms that are said to be basic to being human. Do unto others as you would have them do unto you. Show hospitality to others and honour your guest (note

\footnotetext{
${ }^{2}$ An ethics of care has many lineages, and the position developed here does not align with any particular author, but it draws foundationally on the feminist lineage that includes writers such as Joan Tronto (1993). For an elaboration of ontological differences between ethical approaches, and the beginnings of an alternative in relation to one theme - cosmopolitanism — see James (2014).
} 
here that the words hospital and hospitality are etymologically linked). An ontologically grounded ethics of care has the capacity to work with these generalizing axioms - they are surprisingly common across different traditions - while not necessarily taking on their search for the immanent-transcendental exemplifiers of such practices.

Constructivist ethics by comparison sought, more or less, to stand alone by the eighteenth century in relation to these two prior forms, even if many transitional documents such as Thomas Paine's The Rights of Man still appealed to natural law (with "natural" now in lower case). Kant's categorical imperative was one turning point here, in effect universalizing the "do unto others" injunction as means not ends. While dominant forms of contemporary constructivism take this in a codifying direction, it is possible to develop an alternative pathway, one that is critical of its own rationalism and able to codify but in a contingent way. Writers from Joan Tronto (1993) to Maria Puig de la Bellacasa (2017) have provided us with different ways of thinking that I can only gesture to here, but they require us, at the very least, to consider working back and forth between impure on-the-ground engagement and reflexive consideration of generalized principles that themselves will come into tension with each other.

In these terms, an alternative ethics of care would not be making lists, dividing "high priority" and "low priority" patients, and making pronouncements on whose lives we should be valuing more. It would be working with constituencies and affected communities, and across civil and political society, to initiate dialogue and action on these matters. It might even come up with written principles and guidelines, but it would not start with necro-procedures. And it certainly would not evoke the tragedy of lifeboat ethics or comfortable thinking about the lesser importance of the elderly. What is the value of a ninety-year-old life? A philosophy or politics that begins with that question invites invidious counterquestioning.

\section{References}

Bauman, Z. 1993. Postmodern ethics. Cambridge: Blackwell.

Braidotti, R. 2006. Transpositions: On nomadic ethics. Cambridge: Polity.

de la Bellacasa, M.P. 2017. Matters of care: Speculative ethics in more than human worlds. Minneapolis: University of Minnesota Press.

Dawson, A., D. Isaacs, M. Jansen, et al. 2020. An ethics framework for making resource allocation decisions within clinical care: Responding to COVID-19. Journal of Bioethical Inquiry 17(4): https://doi.org/10.1007/s11673-020-10007-w.

Fouad, M.N., J. Ruffin, and M. Vickers. 2020. COVID-19 is disproportionately high in African Americans: This will come as no surprise ... American Journal of Medicine 133(10): https://doi.org/10.1016/j.amjmed.2020.04.008.

Hardin, G. 1974. Lifeboat ethics: The case against helping the poor. Psychology Today 8: 38-43.

James, P. 2014. Engaged cosmopolitanism: Reconciling local grounding and distance. Arena Journal 41-42: 146-173.

Le Grand, C. 2020. Melbourne Uni chief says Victoria must address difficult ethical questions. The Sydney Morning Herald, September 19.

Millett, G.A., A.T. Jones, D. Benkesser, et al. 2020. Assessing differential impacts of COVID-19 on black communities. Annals of Epidemiology 47: 37-44.

Mukandi, B. 2020. Thinking through COVID-19. Bryan Mukandi Blog, March 30. www.bryanmukandi.com/blog/thinkingthrough-covid-19. .

Rawls, J. 1971. A theory of justice. Oxford: Oxford University Press.

Tronto, J. 1993. Moral boundaries: A political argument for an ethic of care. New York: Routledge.

Valerio, M.A.G., and R. Martínez Ruiz. 2020. Triage: Deciding the ethically undecidable. Critical Times. In the Midst [Blog], May 5. https://ctjournal.org/2020/05/05/triage-deciding-theethically-undecidable/. .

Publisher's note Springer Nature remains neutral with regard to jurisdictional claims in published maps and institutional affiliations. 